\title{
Ekstrak Etanol Sarang Semut Menyebabkan Kerusakan Struktur Histologi Ginjal Mencit
}

\author{
(ETHANOL EXTRACT OF MYRMECODIA PENDANS CAUSED HISTOLOGICAL \\ STRUCTURE DAMAGE OF MICE KIDNEY)
}

\author{
Dini Hilary Manullang ${ }^{1 *}$, I Wayan Sudira ${ }^{2}$, I Ketut Berata ${ }^{3}$, I Made Merdana ${ }^{2}$ \\ ${ }^{1}$ Praktisi Dokter Hewan Kota Medan, Sumarta Utara. \\ ${ }^{2}$ Laboratorium Farmakologi Veteriner, Fakultas Kedokteran Hewan, Universitas Udayana, \\ Denpasar-Bali. ${ }^{3}$ Laboratorium Patologi Veteriner, Fakultas Kedokteran Hewan, Universitas \\ Udayana, Denpasar-Bali. \\ *Email: hilary_dini@yahoo.com
}

\begin{abstract}
ABSTRAK
Analisis kimia menunjukkan bahwa tumbuhan sarang semut (Myrmecodia pendans) memiliki berbagai kandungan senyawa kimia dari golongan flavonoid, tannin, tokoferol, multimineral dan polisakarida. Penelitian ini bertujuan mengetahui pengaruh ekstrak etanol sarang semut terhadap gambaran histopatologi ginjal mencit (Mus musculus) jantan. Penelitian ini menggunakan 24 ekor mencit jantan dengan umur 10-12 minggu yang secara klinis dinyatakan sehat dengan berat 25-35 g. Secara acak seluruh mencit dibagi menjadi 4 kelompok perlakuan, masing-masing kelompok perlakuan terdiri atas 6 ekor mencit. Kelompok P0 adalah kelompok kontrol negatif yang diberikan pakan standar dan aquades, $\mathrm{P} 1$ adalah kelompok yang diberikan pakan standar dan ekstrak etanol sarang semut dengan dosis $100 \mathrm{mg} / \mathrm{kg} \mathrm{BB}, \mathrm{P} 2$ adalah kelompok yang diberikan pakan standar dan ekstrak etanol sarang semut dengan dosis $200 \mathrm{mg} / \mathrm{kg} \mathrm{BB}, \mathrm{P} 3$ adalah kelompok yang diberikan pakan standar dan ekstrak etanol sarang semut dengan dosis $300 \mathrm{mg} / \mathrm{kg}$ BB. Setelah perlakuan selesai pada hari ke-21, organ ginjal diambil untuk dibuat preparat histologi dan diwarnai dengan metode haematoksilin-eosin. Variabel yang diperiksa adalah perdarahan, degenerasi melemak, dan nekrosis di tubulus proksimal ginjal. Hasil uji Kruskall-Wallis menunjukkan pemberian ekstrak etanol sarang semut berpengaruh nyata $(\mathrm{P}<0,05)$ terhadap timbulnya perdarahan pada tubulus ginjal. Berdasarkan hasil penelitian ini dapat disimpulkan bahwa ekstrak etanol sarang semut dengan dosis $300 \mathrm{mg} / \mathrm{kg}$ BB dapat menyebabkan perubahan histopatologi ginjal berupa perdarahan, degenerasi melemak, dan nekrosis.
\end{abstract}

Kata kunci: Flavonoid; ginjal; sarang semut (Myrmecodia pendans); tubulus proksimal

\begin{abstract}
Chemical analysis of the ant-plant (Myrmecodia pendans) showed that plants have various chemical compounds of flavonoids, tannins, tocopherols, multimineral and polysaccharides. The aim of this study was to find out the effect of ethanolic extract of ant-plant on histopathological changes in male mice (Mus musculus) kidney. Twentyfour clinically healthy mice at aged 10-12 with weight 25 to $35 \mathrm{~g}$ were obtained for this study. The sample were divided into four groups randomly, each treatment group consisted of six mice. Group P0 is the negative control group were given standard feed and drink, P1 is a group were given standard feed and ethanol extracts ant plant with a dose of $100 \mathrm{mg} / \mathrm{kg}$ body weight, P2 is a group were given standard feed and ethanol extracts ant plant with a dose of $200 \mathrm{mg} / \mathrm{kg}$ of body weight, P3 is a group were given standard feed and ethanol extracts ant plant with a dose of $300 \mathrm{mg} / \mathrm{kg}$. After completion of the treatment on the day, the kidney was taken for histological preparations were made and stained with the hematoxylin-eosin method. The variables examined were haemorrhage, degeneration and necrosis in the renal proximal tubules. The Kruskal-Wallis test results showed that ethanol extract of ant-plant had a significant effect $(\mathrm{P}<0.05)$ on the incidence of hemorrhage in the renal tubules. Based on these results it can be concluded that the ethanol extract of ant-plant with a dose of $300 \mathrm{mg} / \mathrm{kg}$ body weight can cause kidney histopathological changes such as hemorrhage, degeneration, and necrosis.
\end{abstract}

Keywords: Flavonoids; kidney; ant plant (Myrmecodia pendans); proximal tubule 


\section{PENDAHULUAN}

Tumbuhan sarang semut merupakan anggota Family Rubiaceace, dan dapat berasosiasi dengan semut. Sarang semut merupakan tumbuhan epifit dari suku Rubiaceae yang menempel di pohon-pohon besar, yang batang bagian bawahnya menggelembung berisi rongga-rongga yang dihuni sarang semut jenis tertentu pada ketinggian $2400 \mathrm{~m}$ di atas permukaan laut (Simanjuntak dan Subroto, 2010).

Analisis kimia menunjukkan bahwa tumbuhan sarang semut mengandung senyawa-senyawa kimia terutama dari golongan flavonoid, tannin, tokoferol, multimineral dan polisakarida.

Sarang semut mengandung antara lain flavonoid, tanin, polifenol, dan triterpenoid (Subroto dan Saputro, 2006). Flavonoid adalah keluarga besar senyawa sintesis dari tanaman yang memiliki struktur kimia umum dari bagian polifenol. Flavonoid merupakan antioksidan alam yang mampu bertindak sebagai pereduksi radikal hidroksil, superoksida dan radikal peroksil (Harun dan Syari 2002). Senyawa flavonoid merupakan antioksidan yang sangat penting dalam menetralkan dan menghancurkan radikal bebas (Silalahi, 2002). Pada umumnya flavonoid terdiri dari dua cincin aromatik, masing-masing berisi setidaknya satu hidroksil, yang dihubungkan melalui tiga-karbon dan menjadi bagian dari cincin heterosiklik (Beecher, 2003). Flavonoid selain bertindak sebagai antioksidan yang memiliki manfaat bagi kesehatan manusia juga sebagai antiproliferasi, antikarsinogenik, antibakteri, efek antiinflamasi, antialergi, dan antivirus (Merken dan Beecher, 2000; Leong et al., 2008; Tian et al., 2009; Ajila et al., 2010; Davide et al., 2011; Adam et al., 2013). Tanin mempunyai aktivitas antiinflamasi, namun mekanismenya belum bisa dijelaskan (Khanbabae dan Ree, 2001). Selain itu ekstrak sarang semut dapat menghambat aktivitas enzim santin oksidase. Aktivitas tersebut setara dengan allopurinol, obat komersial yang digunakan untuk pengobatan asam urat atau gout (salah satu jenis penyakit rematik) (Alam dan Waluyo, 2006). Flavonoid juga bekerja sebagai antioksidan yang dapat membentuk mekanisme pertahanan sel terhadap kerusakan akibat radikal bebas (Manna et al., 2009). Fenomena ini yang kemungkinan dapat memperkuat khasiat tumbuhan sarang semut untuk pengobatan asam urat yang telah terbukti secara empiris (Subroto dan Saputro, 2006; Syahnur, 2011). Fenomena ini yang kemungkinan dapat memperkuat khasiat tumbuhan sarang semut untuk pengobatan asam urat yang telah terbukti secara empiris (Subroto dan Saputro, 2006; Syahnur, 2011).

Ginjal merupakan organ eksresi utama yang sangat penting untuk mengeluarkan sisa-sisa metabolisme tubuh, termasuk zatzat toksik yang tidak sengaja masuk ke dalam tubuh. Pemberian senyawa-senyawa yang bersifat toksik ataupun senyawasenyawa yang bersifat iritatif dapat menimbulkan perubhan-perubahan degeneratif seperti degenerasi melemak sampai nekrosis (Guyton, 1997; Katzung, 2001).

Penulisan artikel ini bertujuan untuk mengetahui perubahan histopatologi ginjal mencit (Mus musculus) setelah diberikan ekstrak sarang semut dan mengetahui perbedaan gambaran histopatologi ginjal mencit (Mus musculus) setelah pemberian ekstrak sarang semut (Myrmecodia pendans) dengan dosis 100,200 , dan 300 $\mathrm{mg} / \mathrm{kg} \mathrm{BB}$.

\section{METODE PENELITIAN}

\section{Sampel dan Perlakuan}

Sampel yang digunakan adalah mencit jantan (Mus musculus), dengan jumlah 24 ekor, berumur 10-12 minggu, kondisi sehat dan tidak cacat fisik. Tumbuhan sarang semut diperoleh dari Kabupaten Wamena, Provinsi Papua. Pemberian ekstrak sarang semut diberikan secara oral dengan dosis ekstrak sarang semut adalah $100 \mathrm{mg} / \mathrm{kg}$ $\mathrm{BB} /$ hari pada kelompok I, $200 \mathrm{mg} / \mathrm{kg}$ $\mathrm{BB} /$ hari pada kelompok II, dan $300 \mathrm{mg} / \mathrm{kg}$ $\mathrm{BB} /$ hari pada kelompok IV selama 21 hari. Sedangkan kelompok kontrol diberikan 
aquades streril secara oral.

\section{Ekstraksi Sarang Semut}

Sarang semut dicuci bersih dan ditiriskan, kemudian dikering anginkan di bawah sinar matahari tidak secara langsung. Kemudian sarang semut yang sudah dikeringkan, dirajang kecil-kecil, dimasukkan ke dalam blender digiling sampai halus. Hasil blender yang sudah menjadi serbuk dimasukkan ke dalam stoples yang bersih. Serbuk kemudian dimaserasi dengan larutan etanol 96\% selama 48 jam dan diambil filtratnya dengan metode penyaringan dengan kertas saring Whatman no. 42 sehingga didapat ekstrak etanol. Hasil saringan kemudian diuapkan dalam vacum rotary evaporator pada temperatur $45^{\circ} \mathrm{C}$, sampai seluruh pelarut menguap dan disimpan dalam refrigerator dengan suhu $10^{\circ} \mathrm{C}$.

\section{Pembuatan Preparat Histopatologi}

Setelah mencit diberi perlakuan selama 21 hari dilanjutkan dengan nekropsi dan ginjal diambil dan dipotong dengan ukuran $1 \times 1 \times 1 \quad \mathrm{~cm}$ untuk dibuat preparat histopatologi, kemudian direndam dalam larutan neutral buffer formalin (NBF). Sampel organ selanjutnya diperkecil lagi dengan irisan tipis untuk disimpan dalam tissue cassette dan dilakukan fiksasi dalam larutan NBF. Setelah fiksasi, dilakukan proses dehidrasi dan clearing dengan satu sesi larutan yang terdiri dari: alkohol $70 \%$, alkohol 80\%, alkohol 90\%, alkohol 96\%, alkohol absolut, toluene, dan parafin, secara bertahap dalam waktu satu hari. Sampel organ diblocking dengan embedding set yang dituangi parafin cair kemudian didinginkan. Blok yang sudah dingin dipotong menggunakan microtome dengan ketebalan $\pm 4-5$ mikron. Proses yang terakhir adalah pewarnaan dengan metode Harris hematoksilin-eosin (HE) dan mounting media (Kiernan, 1990).

\section{Variabel penelitian}

Selanjutnya preparat jaringan diperiksa dibawah mikroskop dengan pembesaran
400× pada bagian tubulus proksimal dengan 5 lapang pandang mikroskopik pada masing-masing perlakuan. Pemeriksaan histopatologi ginjal meliputi perubahan pada tubulus proksimal meliputi: perdarahan, degenerasi melemak, dan nekrosis dengan nilai skoring sebagai berikut

Skor 0: tidak ada perdarahan, degenerasi melemak, dan nekrosis.

Skor 1: perdarahan, degenerasi melemak, dan nekrosis bersifat fokal.

Skor 2: perdarahan, degenerasi melemak, dan nekrosis bersifat multifokal.

Skor 3: perdarahan, degenerasi melemak, dan nekrosis bersifat difusa.

\section{Analisis Data}

Data skoring yang diperoleh masingmasing dianalisis dengan uji non parametrik Kruskal Wallis. Jika berbeda nyata $(\mathrm{P}<0,05)$, maka dilanjutkan dengan uji Mann Whitney. Semua analisis data menggunakan program SPSS.

\section{HASIL DAN PEMBAHASAN}

Hasil penelitian menunjukkan ada beragam perubahan sesuai dengan variabel yang diperiksa. Adapun rerata hasil skoring perdarahan, degenerasi melemak, dan nekrosis pada masing-masing perlakuan dapat disajikan pada Tabel 1 dibawah ini.

Tabel 1 Data Hasil Pemeriksaan Mikroskopis Perubahan Histopatologi Ginjal

\begin{tabular}{lccc}
\hline \multirow{2}{*}{ Perlakuan } & \multicolumn{3}{c}{ Perubahan Mikroskopis } \\
\cline { 2 - 4 } & A & B & C \\
\hline P0 & 0,3 & 0 & 0,3 \\
P1 & 2 & 0 & 1,3 \\
P2 & 2,3 & 0 & 1 \\
P3 & 2,3 & 0,3 & 1,3 \\
\hline
\end{tabular}

Keterangan: P0. kontrol negatif; P1. ekstrak etanol sarang semut dosis $100 \mathrm{mg} / \mathrm{kg} \mathrm{BB}$; P2. ekstrak etanol sarang semut dosis 200 $\mathrm{mg} / \mathrm{kg} \mathrm{BB}$; P3. ekstrak etanol sarang semut dosis $300 \mathrm{mg} / \mathrm{kg}$ BB. A. Perdarahan; B. Degenerasi melemak; C. Nekrosis 
Hasil uji Kruskal-Wallis menunjukkan $\mathrm{P}=0,041$, yang menunjukkan perbedaan nyata antara kelompok kontrol negatif dengan kelompok perlakuan $(\mathrm{P}<0,05)$. Sedangkan degenerasi melemak, menunjukkan tidak terdapat perbedaan nyata antara kelompok negatif dengan kelompok perlakuan $(\mathrm{P}>0,05)$. Untuk lesi nekrosis, menunjukkan tidak terdapat perbedaan nyata antara kelompok negatif dengan kelompok perlakuan $(\mathrm{P}>0,05)$. Hal ini berarti bahwa pemberian ekstrak etanol sarang semut berpengaruh nyata $(\mathrm{P}<0,05)$ terhadap adanya perdarahan, tetapi tidak berpengaruh nyata $(\mathrm{P}>0,05)$ terhadap adanya degenerasi melemak dan nekrosis pada ginjal mencit.

Hasil uji Mann-Whitney untuk perdarahan antara kelompok kontrol negatif (P0) dengan kelompok kontrol P1, P2 dan $\mathrm{P} 3$ menunjukkan perbedaan nyata $(\mathrm{P}<0,05)$. Tetapi antara kelompok kontrol P1 dengan P2 dan P3 tidak menunjukkan perbedaan yang nyata $(\mathrm{P}>0,05)$.

Hasil pemeriksaan mikroskopis dari masing-masing pemberian ekstrak etanol sarang semut terhadap gambaran histopatologi ginjal mencit antara dosis 100 $\mathrm{mg} / \mathrm{kg} \mathrm{BB}, 200 \mathrm{mg} / \mathrm{kg} \mathrm{BB}$, dan $300 \mathrm{mg} / \mathrm{kg}$ BB disajikan pada Gambar 1 s.d 4.

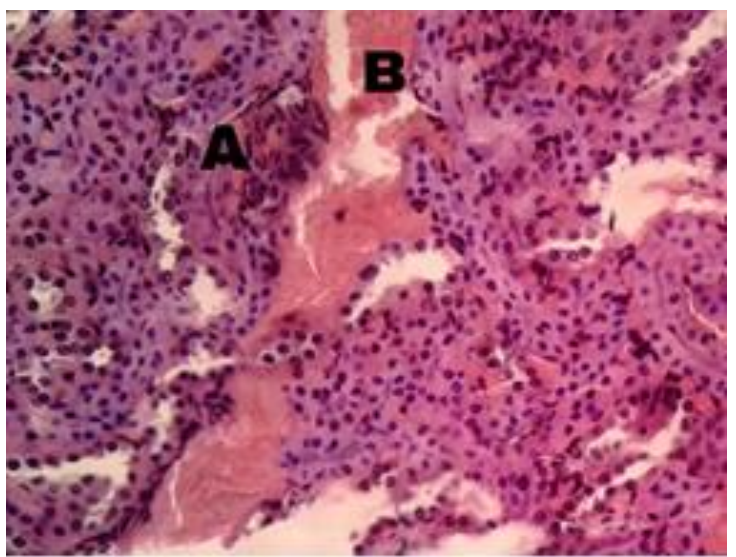

Gambar 1. Gambaran histopatologi ginjal mencit (Mus musculus) P0 (HE, 400×). Terlihat adanya perdarahan dan nekrosis. Terlihat adanya nekrosis (A) dan perdarahan (B).

Hasil pengamatan gambaran mikroskopis tubulus proksimal ginjal mencit menunjukkan adanya variasi lesi perdarahan, degenerasi melemak, dan nekrosis. Kerusakan terjadi pada seluruh kelompok mencit baik kontrol maupun kelompok yang diberi ekstrak etanol sarang semut dosis $100 \mathrm{mg} / \mathrm{kg} \mathrm{BB}, 200 \mathrm{mg} / \mathrm{kg} \mathrm{BB}$, dan $300 \mathrm{mg} / \mathrm{kg}$ BB. Lesi perdarahan pada pemberian ekstrak etanol sarang semut dosis $100 \mathrm{mg} / \mathrm{kg} \mathrm{BB}, 200 \mathrm{mg} / \mathrm{kg} \mathrm{BB}$, dan $300 \mathrm{mg} / \mathrm{kg}$ BB tampak meningkat. Hal ini mungkin merupakan tanda perbaikan dari sel-sel akibat pemberian ekstrak sarang semut. Berata et al (2011) melaporkan bahwa pada jaringan yang mengalami perbaikan umumnya terjadi peningkatan vaskularisasi, sehingga tampak seperti perdarahan.

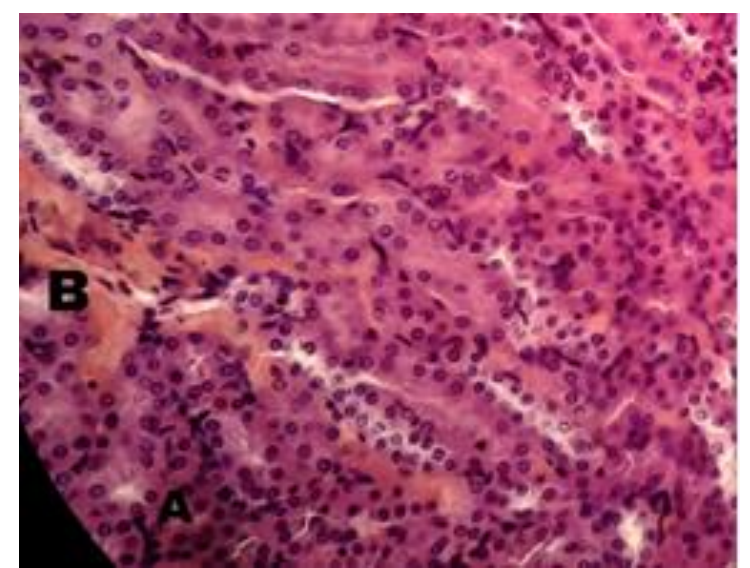

Gambar 2. Gambaran histopatologi ginjal mencit (Mus musculus) P1 (HE, 400×). Terlihat adanya perdarahan dan nekrosis. Terlihat adanya nekrosis (A) dan perdarahan (B).

Lesi degenerasi melemak pada kelompok kontrol dan ekstrak sarang semut, dosis $100 \mathrm{mg} / \mathrm{kg} \mathrm{BB}$, dan $200 \mathrm{mg} / \mathrm{kg}$ BB tidak tampak. Hal ini menunjukkan bahwa sampai dosis $200 \mathrm{mg} / \mathrm{kgBB}$ tidak terjadi gangguan metabolisme pada sel tubulus ginjal. Tetapi pada pemberian ekstrak etanol sarang semut dosis 300 $\mathrm{mg} / \mathrm{kg}$ BB tampak ada lesi degenerasi melemak. Lesi ini menandakan adanya gangguan metabolisme pada sel tubulus ginjal akibat toksisitas.

Degenerasi melemak merupakan akumulasi droplet lemak berbutir (vakuola) yang terjadi di dalam sitoplasma sel. Degenerasi melemak pada ginjal ditemukan 
di daerah korteks, terutama pada tubulus ginjal (Cotran et al., 1992). Keadaaan tersebut menandakan terjadinya keracunan tubular yang disebabkan oleh zat toksik seperti logam berat dan racun tumbuhan. Tanda utama terjadinya keracunan tubular berupa degenerasi melemak dan nekrosis pada tubulus (Nabib, 1987). Degenerasi melemak disebabkan oleh substansi zat toksik, defisiensi nutrisi, defisiensi substansi lipotrofik, dan diet lemak tinggi (Carlton dan McGavin, 1995).

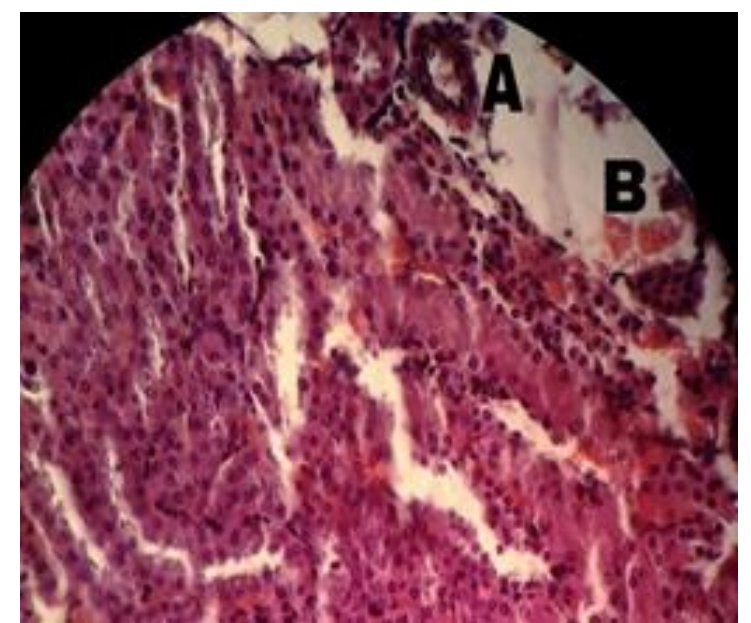

Gambar 3. Gambaran histopatologi ginjal mencit (Mus musculus) P2 (HE, 400×). Terlihat adanya perdarahan dan nekrosis. Terlihat adanya nekrosis (A) dan perdarahan (B).

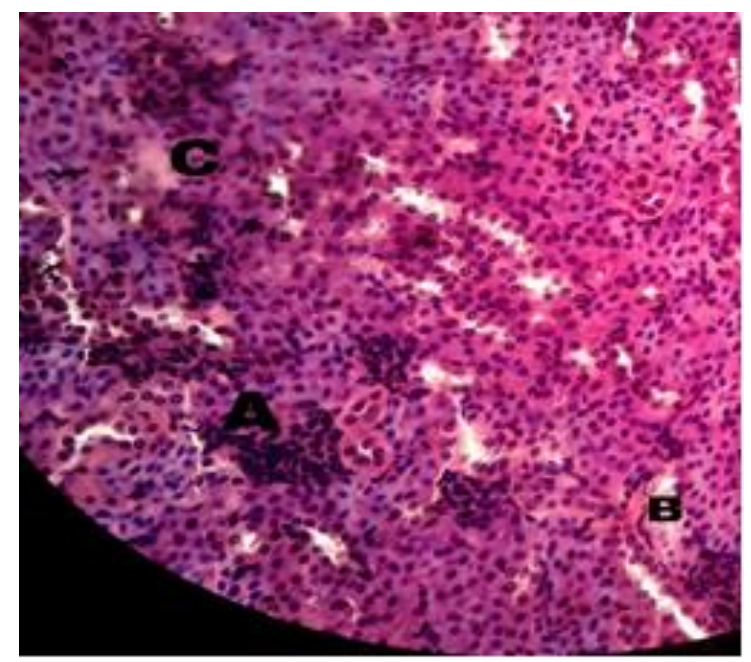

Gambar 4. Gambaran histopatologi ginjal mencit (Mus musculus) P3 (HE, 400×). Terlihat adanya perdarahan (A), nekrosis.(B), dan degenerasi melemak (C).
Lesi nekrosis pada pemberian ekstrak etanol sarang semut dosis $100 \mathrm{mg} / \mathrm{kg}$ BB dan $300 \mathrm{mg} / \mathrm{kg}$ BB tampak sama, tetapi lesi nekrosis sedikit pada dosis $200 \mathrm{mg} / \mathrm{kgBB}$. Hal ini mungkin berkaitan dengan penggunaan mencit yang tidak Spesific Pathogen Free (SPF). Nekrosis atau kematian sel adalah kerusakan lanjutan dari degenerasi parenkimatosa yang bersifat irreversibel. Proses kematian sel berlangsung lebih cepat daripada proses regenerasi, sehingga sel-sel mati terakumulasi pada jaringan. Sel yang mati dikenali tubuh sebagai benda asing, sehingga sel mati tersebut selalu dikelilingi oleh sel-sel radang. Jaringan nekrosis secara mikroskopik akan mengalami berbagai perubahan berupa piknosis, karyorheksis, ataupun karyolisis (Berata et al, 2011).

Terdapat beberapa perubahan yang mendahului nekrosis, yaitu edema sitoplasma, dilatasi retikulum endoplasma, lisisnya inti dan organel sel, dan pecahnya membran plasma (Lu, 1991). Nekrosis yang bersifat fokal dapat digantikan oleh sel yang sehat melalui proses regenerasi sel jika penyebabnya dihilangkan. Sedangkan pada kasus nekrosis difusa, sel yang mati akan digantikan oleh jaringan ikat (sirosis) (Ressang, 1984).

\section{SIMPULAN DAN SARAN}

\section{Simpulan}

Terdapat perubahan gambaran histopatologi ginjal mencit (Mus musculus) jantan pada pemberian ekstrak etanol tumbuhan sarang semut (Myrmecodia pendans) dosis $100 \mathrm{mg} / \mathrm{kg} \mathrm{BB}, 200 \mathrm{mg} / \mathrm{kg}$ $\mathrm{BB}$, dan $300 \mathrm{mg} / \mathrm{kg} \mathrm{BB}$ berupa perdarahan, degenerasi melemak, dan nekrosis. Ada perbedaan lesi perdarahan antara kontrol dengan dosis $100 \mathrm{mg} / \mathrm{kg} \mathrm{BB}, 200 \mathrm{mg} / \mathrm{kg}$ $\mathrm{BB}$, dan $300 \mathrm{mg} / \mathrm{kg} \mathrm{BB}$, tetapi lesi degenerasi melemak dan nekrosis tidak berbeda nyata antara kontrol dengan pemberian ekstrak dosis $100 \mathrm{mg} / \mathrm{kg} \mathrm{BB}$, $200 \mathrm{mg} / \mathrm{kg} \mathrm{BB}$, dan $300 \mathrm{mg} / \mathrm{kg} \mathrm{BB}$. 


\section{Saran}

Perlu dilakukan penelitian lebih lanjut mengenai penggunaan ekstrak etanol tumbuhan sarang semut (Myrmecodia pendans) pada mencit betina untuk mengetahui efeknya terhadap gambaran histopatologi pada ginjal .

\section{UCAPAN TERIMA KASIH}

Penulis mengucapkan terima kasih kepada Laboratorium Farmakologi dan Laboratorium Patologi FKH Unud, yang telah memberikan fasilitas dalam penelitian ini.

\section{DAFTAR PUSTAKA}

Adam ME, Novi SK, Yeshitila AT, Suryadi I, Lien HH, Yi-Hsu J. 2013. Extraction,identification and quantitative HPLC analysis of flavonoids from sarangsemut (Myrmecodia pendens). Ind. Crops. Products. 41: 392-396.

Ajila CM, Rao LJ, Rao UJ. 2010. Characterization of bioactive compounds from raw and rip Mangifera indica L. peel extracts. Food Chem. Toxic. 48:3406-3411.

Alam S, Waluyo S. 2006. Sarang Semut Primadona Baru dari Papua. Majalah Nirmala. PT Gramedia. Pustaka Utama. Jakarta.

Beecher GR. 2003. Overview of dietary flavonoids: nomenclature, occurrence and intake. J. Nutr. 133:3248S-3254S.

Davide B, Ersilia B, Corrado C, Ugo L, Giuseppe G. 2011. Distribution of Cand O-glycosyl flavonoids (3-hydroxy3 methylglutaryl)glycosyl flavanones and furocoumarins in Citrus aurantium L. juice. Food Chem. 124: 576-582.

Guyton AC, Hall JE. 1997. Ginjal dan Cairan Tubuh. In: Setiawan I, Editor. Buku Ajar Fisiologi Kedokteran. 9th ed. Jakarta: EGC; Pp. 375-437.

Harun N, Syari W. 2002. Aktivitas antioksidan ekstrak daun dewa dalam menghambat sifat hepatotoksik halotan dengan dosis sub anastesi pada mencit. J. Sains Teknol. Farm.7(2): 63-70.
Katzung BG. 2001. Farmakologi Dasar dan Klinik. Vol. 1. Jakarta: EGC.

Khanbabae K, Van RT. 2001. Tannins: Classification and Definition. Nat. Prod. Rep. 18: 641-49.

Kiernan JA. 1990. Histological dan Histochemical Methods: Theory and Practice. $2^{\text {nd }}$ Ed. Pergamon Press. Pp. 330-354.

Leong CN, Tako M, Hanashiro I, Tamaki H. 2008. Antioxidant flavonoid glycosides from the leaves of Ficus pumila L. Food Chem. 109(2): 415-420.

$\mathrm{Lu}$ FC. 1991. Basic Toxicology: Fundamentals, Target Organs, and Risks Assements, diterjemahkan oleh Edi Nugroho, 47, Hemisphere Publishing Corporation, Washington DC.

Manna P, Sinha M, Edward PC. 2009. Protective Role of Arjunolic Acid in Response to Streptozotocin Induced Type-I Diabetes via Mitochondrial Dependent and Independent Pathways. Toxicol. 257: 53-56.

Merken HM dan Beecher GR. 2000. Liquid chromatographic method for the separation and quantification of prominent flavonoid aglycones. $J$. Chromatography. 897: 177-184.

Nabib R. 1987. Patologi Khusus Veteriner. Edisi 2 Proyek Peningkatan Pengembangan Perguruan Tinggi. IPB.

Resang AA. 1984. Patologi Khusus Veteriner. 2nd Ed. Percetakan Denpasar. Pp. 25-248.

Silalahi J. 2002. Senyawa polifenol sebagai komponen aktif yang berkhasiat dalam teh. Majalah Kedokteran Indonesia. 52(10): 361-4.

Simanjuntak F dan Subroto MA. 2010. Isolasi Senyawa Aktif dari Ekstrak Hipokotil Sarang Semut (Myrmecodia pendens Merr. dan Perry) sebagai Penghambat Xantin oksidase. J. Ilmu Kefarmasian Indonesia. 8(1): 49-54.

Subroto MA, Saputro H. 2006. Gempur Penyakit dengan Sarang Semut. Penebar Swaday, Jakarta. Pp. 21-28. 
Syahnur SR. 2011. Isolasi dan Karakterisasi Triterpenoid dari Tumbuhan Sarang Semut. Skripsi. Universitas Andalas. Padang.
Tian XJ, Yang XW, Yang X, Wang K. 2009. Studies of intestinal permeability of 36 flavonoids using Caco-2 cell monolayer model. Int. J. Pharm. 367: 58-64. 